\title{
Quilombola School Education from a Field Perspective: The Quilombola Peasant
}

La educación escolar quilombola desde la perspectiva del hombre del campo: el campesino quilombola

Educação Escolar Quilombola na Perspectiva do homem do Campo: O Camponês Quilombola

Niltânia Brito-Oliveira* (iD orcid.org/0000-0003-3452-7559

Arlete Ramos dos Santos ** (ID) orcidorg/0000-0003-0217-3805 Igor Tairone Ramos dos Santos ${ }^{* * *}$ (D) orcid.org/0000-0003-7796-240|

Para citar este artículo: Brito- Oliveira, N., Ramos dos Santos, A. y Ramos dos Santos, I. (2020). Quilombola School Education from a Field Perspective: The Quilombola Peasant. Revista Colombiana de Educación, 1(80), 377-396. https://doi.org/10.17227/rce.num80-10802

\begin{tabular}{|c|c|}
\hline (c) $\bigoplus_{\mathrm{BY}} \$$ & $\begin{array}{r}\text { Recibido: 28/11/2019 } \\
\text { Evaluado: 12/05/2020 }\end{array}$ \\
\hline
\end{tabular}

* Mestre em Educação em uEsc. Prefeitura Municipal de Vitória da Conquista, Brasil. Correo electrónico: africa.niltania@gmail.com

** Pós-doutorado em Educação pela ufMG. Universidade Estadual do Sudoeste da Bahia - UESB, Brasil. Correo electrónico institucional - arlerp@hotmail.com

*** Mestre em Educação pela UESB. Universidade Estadual do Sudoeste da Bahia - UESB, Brasil. Correo electrónico: ramosdossantosigortairone(a)gmail.com 


\begin{abstract}
This article is a product of an ongoing research entitled: "The educational public policies of the Articulated Action Plan-PAR in municipalities of Bahia". It focuses on Vitória da Conquista, Ilhéus and Itabuna. We describe the results of this study concerning the reality of the quilombola' school education from a field ${ }^{2}$ perspective, that of the quilombola peasant. We followed the dialectical historical materialism method. The results point to contradictions between what the law provides in the specific legislations and the materiality of this population's particularities. We conclude that the specific mode of production of the quilombola countryside people legitimizes a social practice of coping with capital through the peasantry. To better explain it, we have used the emerging category Quilombola peasant.
\end{abstract}

\section{Keywords}

ethnic community; rural education; farmer; constitutional law; brazilian culture

\section{Palabras clave}

comunidad étnica; educación rural; campesino; derecho constitucional; cultura brasileña

\section{Resumen}

Este artículo se deriva de una investigación en desarollo titulada: "Las políticas públicas educativas del plan de acciones articuladas-par en municipios de Bahía" que se centra en Vitória da Conquista, Ilhéus e Itabuna. En él se describen los resultados de este estudio en lo que se refiere a la realidad de la educación escolar quilombola desde la perspectiva del hombre del campo: el campesino quilombola. Se siguió el método del materialismo histórico dialéctico. Los resultados apuntan a contradicciones entre las normativas previstas en las legislaciones específicas y la materialidad de las particularidades de esta población. Concluimos que el modo de producción específico del hombre del campo quilombola legitima una práctica social de enfrentamiento al capital a través del campesinado, y para mejor explicitarla creamos la categoría Campesino quilombola.

\section{Resumo}

Este artigo parte de uma pesquisa em andamento intitulada: "As políticas públicas educacionais do Plano de Ações Articuladas- PAr em municípios da Bahia" a saber Vitória da Conquista, Ilhéus e Itabuna. Entretanto, no particular descreveremos os dados dos resultados deste estudo no que se refere ao recorte sobre a realidade da Educação Escolar Quilombola na Perspectiva do Homem do Campo: o Camponês Quilombola. O método é o materialismo histórico dialético. Os resultados apontam contradições entre as normativas previstas nas legislações específicas e a materialidade das especificidades desta população. Concluímos que o modo de produção específico do homem do campo quilombola legitima uma prática social de enfrentamento ao capital através do campesinato, e para melhor explicitá-la criamos a categoria: O Camponês Quilombola.

\section{Palavras-chave}

comunidade étnica; educação rural; agricultor: direito constitucional; cultura brasileira

1 "[...] the ethnic-racial groups, according to self-attribution criteria, with regional layout, endowed with specific territorial relations, with presence of black ancestry related to the resistance to the oppression suffered" (Brazil, 2003b, p. 2).

2 The article entitled "Peasant educational public policies in the context of Latin America: Notes on Brazil and Venezuela", published in UFMA's Cadernos de Pesquisa is authored by researchers from Venezuela and Brazil, namely: Paulina Elena Villasmil Socorro, Samuel Hilcías Carvajal Ruíz, Arlete Ramos dos Santos, Cláudio Pinto Nunes. The text presents an analysis of neoliberal public policies in the education of the two countries, this type of education being called rural education for Venezuela, and field education for Brazil. The authors point out that in both countries, until the end of the 20th century and in the two decades of the 21 st century, policies for rural education / field education turned to an urban-centric perspective, but due to the dispute between agribusiness and the peasantry as antagonistic classes, many conquests were obtained around the historical project of the working class in this investigated Latin American context (Socorro et al., 2017). 


\section{Introduction}

This article focuses on one aspect of a larger ongoing research project entitled: "Public educational policies of the Articulated Action Plan (in Portuguese, Plano de Ações Articuladas- PAR PAR) in municipalities of Bahia", ${ }^{3}$ The purpose of the project is to discuss the impact of PAR on field education ${ }^{4}$ in three Brazilian municipalities, namely: Vitória da Conquista, Itabuna and Ilhéus. As a product of this broader research, we only discuss Quilombola School Education, considering the data collected in the field quilombola schools in the city of Vitória da Conquista. The research methodology was based on dialectical historical materialism, going from the whole to the singular, passing through the particular case here proposed. As it is still important to notice, in order to carry out the study here proposed, we used the bibliographic review and semi-structured interviews.

This text is divided into four parts. In the first part, we present the context of the Quilombola School Education in Brazil and Bahia. In the second part, we focus on the Quilombola School Education from the field inhabitants perspective in the city of Vitória da Conquista-Bahia. The third part describes the research methodology as well as the analysis of the results, from which the Quilombola peasant category emerges as a result of the phenomena observed through the empirical data. Finally, we present the preliminary conclusions of the research.

However, the whole discussion in this article starts from the comprehension of the whole, involving the subjects of the quilombola field and the capitalist society, which designates basic elements that confront and antagonize in the materiality of the working class' claims. It is based upon the accumulation of capital that generates surplus value, which entails the compulsory exploitation that led to the loss of land ownership and to the elementary living conditions of the individuals coming from the countryside, called quilombola peasants ${ }^{5}$ in this research.

3 Research project carried out by the Studies and Research in Social Movements, Diversity and Education of the Field area Group-Gepemdec.

4 In this article, the term field education, following Caldart (2011), refers to the type of school and education that recognizes and helps to strengthen the significance of peasants as social individuals capable of helping in the process of humanization of society as a whole, with their struggles, their history, their work, their knowledge, culture and their way of living. Reaffirming the concept that "[...] A field school is the one that defends the interests of the peasant's farming, their abilities to build knowledge and technologies in the direction of social and economic development of their population" (Arroyo; Fernandes, 1999, p. 47).

5 We created the Quilombola Peasant category to designate native subjects from the field area, living in quilombos, based on family farming with their own resistance to capital. We will explain in detail this category later. 
This historical background led the struggle of the Black and Quilombola movements - as well as that of the Brazilian researchersfor reparation, recognition, valorization, and insertion of black people in society, and the fights against discrimination and racism to overcome class division. It is noteworthy that most of the authors, documents, and people that we cited and interviewed were Brazilians. To present their contributions, we translated their quotes and documents ourselves, taking the risk of any misunderstanding issues that may occur.

\section{Methodology}

The method used is the dialectical historical materialism, that is executed by starting from the understanding of the whole of the capitalist society in the universal, passing through the mediations in the particular which are imbricated into the phenomenon of Quilombola School Education in the singular analyzed in its multiple determinations. The approach is qualitative and seeks to reveal from the analysis of the data the essence of the phenomena.

Minayo (2002, p. 16) states that "methodology is the path of thought and practice in approaching reality, methodology occupies a central place in theories and is always linked to them." Hence, the importance of methodology to unveil reality, which, being imbricated into the multiple determinations of the same reality, needs to be supported by the theories closely related to it (Minayo, 2002). We used as data collection instruments the documental analysis and the interviews gathered in the focus group with 34 teachers who were working at the quilombola schools of Vitória da Conquista-Bahia.

To understand the reality of Quilombola School Education from the perspective of the field people that will be unveiled, we follow Cheptulin (2004) to reflect upon the importance of understanding the categories of analysis and their correlation as a preponderant, essential, and determinant factor connected to the objective reality, in the law of unity and in the struggle of the opposites. That is to say, in the struggle between the bourgeoisie and the working class, especially here as a worker, the quilombola peasant, who suffers all the ills of this capitalist model of compulsory exploitation. This law constitutes the center of dialectics, but it does not determine how the categories will follow or arise, because the movement is dynamic and, therefore, dialectical. The dialog begins with the practice, through which the representations express themselves and form the categories in which the connections and the universal forms of the research subject are reflected and fixed. 


\section{The Contextualization of Quilombola School Education in Brazil and Bahia}

From the post-abolition period, in 1888, to the present day, the inclusion of black people into society remains divided into classes, with a privileged white elite to the detriment of the working population, mostly black. Public policies for the inclusion of black people into the education system became part of the Brazilian social agenda, which contributed to intensify social, economic, and ethnic inequalities for most black population in this country.

Only after the promulgation of the 1988 Federal Constitution, the nation has advanced to meet the specificities of peasants, mainly, those who live in the quilombos. Another very important norm was the 9394 Law, issued in 1996, which established the Guidelines and Bases of National Education. It sets forth educational rights for all, including minorities, such as quilombolas, indigenous people and other social and ethnic minorities.

However, Quilombola School Education in Brazil arose from social contradictions and pressures against neoliberal policies (Brazil, 2003). These pressures were expressed by the organization of the Quilombola Movement and the Black Movement, which brought this problem to the public and political arena, and put it as an important social and educational issue. There are constitutional principles which guarantee the right of quilombola populations to a differentiated education through the Guidelines for Field Education (Brazil, 2002). The norms that contributed significantly to the Quilombola School Education were supported in the 9394/96 Law. This norm amended the article 26-A, which stated:

Curriculum for primary, elementary and secondary education must have a common national basis, to be complemented, in each school system and in each educational establishment, by a diversified sector, which is required by the regional and local characteristics of society, culture, economy and learners. (Drafting provided by the 12.796/2013 Law)

This article was modified to the following wording:

Art. 26-A - In primary and secondary education establishments, public and private, it becomes mandatory to study Afro-Brazilian and indigenous history and culture.

$\S 1$ - The programmatic content which this article refers to, will include various aspects of the history and culture that characterize the formation of Brazilian population, from these two ethnic groups, such as the study of the history of Africa and the Africans, the struggle of black and 
indigenous peoples in Brazil, black and indigenous Brazilian culture and black and indigenous in the formation of national society, rescuing their contributions in the social, economic and political areas, pertinent to the history of Brazil.

$\S 2^{\circ}$ - The contents referring to the history and culture of Afro-Brazilian and indigenous peoples of Brazil will be taught within the scope of the entire school curriculum, especially in the areas of Art Education and Literature and Brazilian History. (Brazil, 1996)

It is noticeable that the article 79-B was amended to add: "The school calendar will include November 20th as 'National Black Awareness Day'". (Included by Law 10.639, dating 9.1.2003). However, the compulsory nature of the Study of Ethnic-Racial Relations, Afro-Brazilian, African and Indigenous History and Culture, becomes an achievement of the Black and Quilombola Movements through laws 10.639/03 and 11.645/08.

However, after Law 10.639/03, the National Council of Education approved CNE/CP Resolution 01 (issued on June 17 $7^{\text {th }}, 2004$ ), which included the Afro-Brazilian and African History and Culture in their curriculum. The discussion about the quilombola reality also counted on the demands and deliberations of the National Conference of Education (Conae).

It was the first time that the National Board of Education considered Quilombola School Education as a teaching modality and recognized that there should be specific regulations for quilombolas in the educational system, to be nationally consolidated, and follow general curricular guidelines of basic education passing through all teaching modalities. In this sense, the consolidation of this teaching modality was supported by the following legislation: CEB/CP Resolution 07, of December 14 ${ }^{\text {th }}, 2010$; CNE/CP Opinion 16 of June 5, 2012; CNE/CP Resolution 8 of March $8^{\text {th }}, 2012$, which deals with the National Plan for the Implementation of the Quilombola School Education Guidelines established by Resolution 08 of November $20^{\text {th }}, 2012$.

Thus, the guidelines included all the necessary organization for the implementation of the policy by the respective federation entities (federal government, states and municipalities): conception, principles, objectives, stages and modalities, political pedagogical project, curriculum, management, evaluation, training of teachers, among others.

In Bahia, discussions about the need to build a state policy for Quilombola School Education appear in 2010, almost in parallel with other states, such as Maranhão and the Federal District. Oliveira (2017) points out that in Bahia, this proposal for interstate policies came about through the creation of the Secretariat for the Promotion of Racial Equality (Sepromi), sanctioned by Law 10.549 of December $28^{\text {th }}$, 2006, which was responsible for elaborating joint proposals with the state and municipalities for 
the enforcement of this policy. Several public hearings were held until reaching the educational proposal for the quilombola communities of the state of Bahia.

As in the rest of the country, the claims of the state of Bahia began with the struggle of the Black and Quilombola Movements to enforce Law 10.639/03, which deals with the Education of Ethnic-Racial Relations and for the Teaching of Afro-Brazilian History and Culture and Africa in basic education and high school in the country's public and private institutions. The Brazilian Studies and Afro Commission (Ceafro) contributed to the implementation of this policy in the state of Bahia with the application of Law 10.639/2003, and in the municipality of Salvador. According to Oliveira (2017), "in 2005 the State Education and Ethnic Racial Diversity Forum was held in the city of Salvador, on the initiative of the General Coordination of Diversity and Educational Inclusion of the Secretariat for Continuing Education, Literacy and Diversity" (Secad/MEC). From this event, forums were created in the Brazilian states to deal with this issue.

However, Decree 7.352, dated November $4^{\text {th }}, 2010$, promotes the recognition of quilombola peoples as subjects of the field areas and defines the location of field schools:

I-Populations of the field areas: family farmers, extractivists, artisanal fishermen, riverine people, settlers and campesinos of agrarian reform, field wage laborers, quilombolas, caiçaras, forest peoples, caboclos and others who produce their material conditions of existence from work in field areas.

II-Field school: one located in a field area, as defined by the Brazilian Institute of Geography and Statistics (IBGE), or one situated in an urban area, provided that it predominantly serves the field population. (Brazil, 2010)

This decree has become a tool to strengthen the policy of field education and opens to the modality of Quilombola School Education when it defines the native populations of the field areas, being the quilombolas one of them, for having their material mode of production associated to deal with the land, the way of resistance, and the cultural, social and environmental specificities of the field people. It also defines the location of field schools, which can be in the countryside and city of the country, since it attends the subjects described above, among them, the quilombolas.

Nevertheless, field education as a state policy became preponderant for the regulation of quilombola school education and gained boom after the -First National Meeting of Educators and Educators of Agrarian ReformEnera, which took place in Brasilia in 1997, and soon after, with the First National Conference for a Basic Field Education, held in Luziânia/Go, in

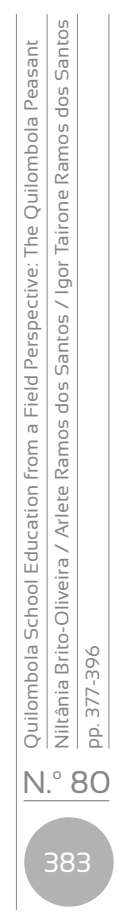


1998, legitimizing the struggles for the identity of peasant education in the different actions since then, and gradually involving a larger group of organizations and entities (Fonec, 2012).

According to Santos (2016),

Initially, the Basic Education of the Field is debated at the National Conference of 1998. Later, the debate for Field Education is expanded, including the school sector, Basic Education, Higher Education, Post-Graduation and public competitions for higher education teachers. What motivated the emergence of this new social practice was the need for unitary struggles made by the workers themselves and their organizations for a public policy of Field Education that would guarantee the right of field populations to education. (p. 168)

Santos (2016) also emphasizes the relevance of the debates and struggles of peasant workers to enforce their rights to an education that fits their specificities, making them subjects of the field areas and builders of their own history. Thus, to problematize the real conditions leading peasants to leave their roots, their lands and seek new opportunities in the city is a preponderant factor for the unveiling of this predatory logic of capitalism that denies the identity of the peasantry, against the policy of education of the emancipatory field. The quilombola peasants are inserted in this reality because they are subjects from the countryside with their own features and own ways of preserving their culture, quite present and necessary today.

\section{The origin of Quilombola School Education from a field perspective in the municipality of Vitória da Conquista-Bahia}

The quilombolas from the countryside have a peasant origin because they bring with them the way of producing material and cultural goods through work in the field areas. It is right there where they make their living and survive. As Garcia and Monteiro (2015, p. 50) point out: "Despite his heterogeneity, peasant rationality and the struggle for land and territory have guaranteed black families a way of life, a way of organizing space, work and life itself." Thus, this peasant rationality makes the quilombolas subjects of the peasantry. That is why we call them quilombola peasants. Researchers such as Munanga (2004) and Gomes (2006) say that the word kilombo originates in the bantu Umbuntu language, spoken by the ovimbundu people, which refers to a type of military sociopolitical institution known in Central Africa, specifically in the area formed by the current Democratic Republic of Congo — formerly Zaire — and Angola. Although 
it is an Umbuntu term, it is constituted in a military group composed of the jagas or imbangalas (of Angola) and of the lundas (of Zaire) in the seventeenth century.

Another definition of quilombos is found in the National Curriculum Guidelines for Quilombola School Education (2012):

The term quilombo has assumed new meanings in the specialized literature and also for groups, individuals and organizations. It is being reassigned to designate the present situation of the black segments in regions and contexts of Brazil. Contemporaneously, quilombo does not refer to residues or archaeological remnants of temporal occupation or biological proof. These are not isolated groups or of a strictly homogeneous population, nor were they always constituted from insurrectionary or rebellious movements. Above all, they consist of groups that have developed daily practices of resistance in the maintenance and reproduction of their characteristic ways of life and in the consolidation of their own territory. The identity of these groups is not defined by size and number of members, but by lived experience and shared versions of their common trajectory and continuity as a group. In this sense, they constitute ethnic groups conceptually defined by anthropology as an organizational type that confers membership through norms and employed means to indicate affiliation or exclusion. (O'd Wyer, 1995, p. 2)

This definition is relevant in terms of understanding the unique ways of life of quilombola peoples and in the formation of their own territories as ways of resistance against the exclusion they have always faced, and for the strengthening of their peasant and quilombola identity. However, Marx (1993, p. 20) states that "it is not the consciousness of men that determines their being, but on the contrary, their social being that determines its consciousness." Therefore, insofar as the social being is constructed, it is constituted in two ends — subjective and objective-, which determine its actions. That is to say, it is subject now, and then object of History.

Thus, Quilombola School Education is intrinsically imbricated with Field Education and becomes an instrument of struggle of the social movements, be they quilombola movements or peasant movements, among others in Brazil, characterized by the historical rescue of these populations and by the valorization and respect for their own culture, and their ways of social and economic production. To better understand this, Santos defines peasantry as:

the set of peasant families existing in a territory, that is, in the context of social relations that are expressed in rules of use (institutions) of natural availability (biomes and ecosystems) and cultural (diffused capacities internalized in people and tangible and intangible infrastructures) of a given geographic space politically defined. (2016, p. 114) 
For this author, the peasantry is the set of peasant families belonging to a certain territory and whose way of existence is in harmony with nature, understanding that land is an intangible cultural good and also a very peculiar form of social and political production. On the contrary, Abramovay (2007), when analyzing the concept of the peasantry, affirms that it is incomprehensible to define it from the point of view of capital, since if the peasantry is given the profit, it will become a capitalist itself. The moment it receives a wage, it becomes a worker, and owns the land. Thus, the social and economic relations established by capital will reduce the diversity of the human dimension of peasants.

The peasantry needs to be analyzed from the historical context where it is inserted, and from the structure of the society where it is reproduced. These factors interfere in the modes of production and social life. Consequently, one cannot lose sight of the fact that the quilombola peasants' subjects addressed here, are linked to the unequal and combined development of capital and to the expanded development of capital reproduction and colonization policies. These subjects are not unknown to capital, but necessary for their reproduction (Abramovay, 2007).

On the Paradigm of Agrarian Capitalism-PCA and the Paradigm of the Agrarian Question-PQA, Santos (2016), following Fernandes (2008), emphasizes that the first paradigm understands that the problems triggering the inequalities arisen from capitalism can be solved starting from the intervention of the State through public policies which integrate family agriculture to the capitalist market. For the Agrarian Question Paradigm $(\mathrm{PQA})$, it becomes incompatible to agree with the capitalist interests because the peasants' longings are antagonistic to such interests. According to Santos (2016), the term family agriculture an ideological content charged with values that promote the viability of capitalism also in the agribusiness. Both Santos and Fernandes defend the term peasant agriculture for its comprehensiveness beyond economic issues and reproduction of capital. It has its roots in the understanding of labor as the essence of the mode of production of peasant life, without neglecting the contradictions that permeate the reality of socially-constructed relations.

In Vitoria da Conquista, IBGE data (2010) reveal a reality that confirms the field exodus of the field population. Graph 1 shows the reality of this municipality as to the distribution of the population in urban and field areas. Following a national tendency, the predominance of population of the municipality in the urban area is evidenced by the graph, while the field population has reduced considerably, mainly during the last decade. This is the result of a phenomenon that can be verified throughout the country, the migration of people from the countryside to the cities. This sounds contradictory, because it is always possible to see the strength of the countryside, even with the exclusion of these people to the city and with the arrival of the 
capitalist-type agribusiness that removes it from its housing environment. We note the need for people's return to the countryside to make the subsistence of cities possible (Santos, 2016). In Vitória da Conquista this phenomenon is not different. There is an urgent need for actions that guarantee the return of these people to the peasant space, to their roots, and the resumption of land work.

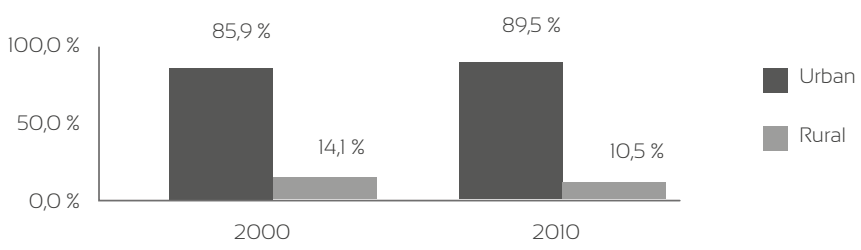

Figure 1. Distribution of the Population of Vitória da Conquista between urban and field areas in the years 2000 and 2010.

SOURCe: IBGE (2O1O).

According to Santos,

The implantation of the agribusiness paradigm in the Brazilian countryside represented the exploitation and/or expropriation of many workers who could no longer withdraw their conditions of existence in the countryside. This economic model broadened and reconfigured the surplus-value and profit-making capacity of the bourgeoisie operating in the agribusiness, being mediated by the legal, political, economic and ideological apparatus of control of the great capital over land and labor force, and deduce from these relations of production between capital and labor a significant increase of the excluded in the country. (2016, p. 63)

The author, through her reflections, reveals and alerts the capitalist policy of denial of field people's rights. She places agribusiness as the effective representative of capitalism to exploit and expropriate the peasants from their lands, excluding workers from society.

Starting from this reality, the movement for a field education has been reversing this logic through its struggles, accumulating an important array of legal instruments that recognize and legitimize the struggles of the field workers. This is a necessary condition for the universality of the right to education to be exercised, respecting the specificities of the subjects of the field areas. Thus, there are some important achievements in educational policies, namely: the Operational Guidelines for Basic Education in the Field Schools, in accordance with resolutions CNE/CEB 1 of April $3^{\text {rd }}$ 2002 and CNE/CEB 2 of April 28 $8^{\text {th }}$ 2008, as a result of these struggles, as well as the CNE/CEB Opinion 1 of February, 2006, which recognizes the 
Alternating Academic Days; Resolution CNE/CEB 4 of July $13^{\text {th }} 2010$, which recognizes Field Education as a specific modality and defines the identity of the field school; Decree 7.352 of November $4^{\text {th }}, 2010$, which provides for the National Policy on Field Education, and the National Program for Education in Agrarian Reform-Pronera (Fonec, 2012).

All of the legal frameworks currently existing as a political action of the Brazilian State in recognition of field and quilombola education, important as they are, still represent a dissociation between the various struggles carried out by the workers.

Mészáros states that

capitalism grants its strategies of domination in an alienating way and in this way the groups of workers cannot succeed precisely because their struggles are solitary, unlike this would be the cooperation between the peoples, the struggle of the working class, from a collective perspective to counteract the hegemony of capital. (2014, p. 64)

The author understands and recognizes the struggles of workers, but criticizes the solitary struggles to favor the alienation of the capitalist system, and urges the working class to seek in the collective the force capable of breaking with the hegemony of capital. Thus, the quilombola peasants as a category is expected to unify the struggles in favor of the working class starting from the whole of determinations embedded into the investigated Brazilian reality, until it arrives at the particular which mediates the singular to unveil the politics of quilombola school education in Vitoria da Conquista. This is the issue addressed here.

\section{The Quilombola peasant in the research results}

For data analysis, we followed the dialectical methodology since "the dialectic is the critical thought that proposes to understand the 'thing in itself' and systematically asks itself how it is possible to arrive at the understanding of the reality" (Kosik, 1997, p. 20).

This research sought to unveil the "thing in itself", and this is the question of the reality of the quilombola field people as the subject being investigated. After analyzing the data using the dialectical method, we created an empirical category to better understand the phenomena evidenced in the research.

For Cheptulin (2004), in order to study the MHD-based laws and categories, it must be observed the Matter, Consciousness, and Practice categories. The analysis of the so-called Quilombola peasant category emerging from this research is supported in the statements of a quilombola school teacher during the interview performed in the focus group: 
and there is already a prejudice on both sides, because he/she is a quilombola, and because he/she is a person in the countryside, he/she is doubly marginalized. We have to break with this paradigm that the individual who is in the field area is aside, just like the quilombola individual too. They have the same right, and they are part of our history. Our history came out of the countryside, of this quilombola people. Our history of Brazil arises from there and it needs to be valued. (Carmen Bispo)

The teacher points to an existing contradiction caused by the totality of the sociometabolic capitalist system, which denies the identity and knowledge of the quilombola peasants. It treats them as inferior to the knowledge standardized in the society they are embedded into, where they suffe the most complex forms of social, economic, cultural, ethnic, and political discrimination. She reveals that it is necessary to break these paradigms and recognizes the historical importance of this subject, who is a peasant because he or she belongs to the field area with very present characteristics of the peasantry, since it is also characteristic of quilombola subjects, as well as for their ethnic belongings built from their historical resistance against socially constructed racial and social exclusion. This assertion also reveals that, for the same reasons, it is clear that they are subjects with peasant and quilombola roots.

This reality highlights the current slaveholding inheritance in Brazil with reflections on the peasant milieu of the remaining communities of the quilombos. As Martins states,

The peasantry was therefore doubly excluded: from the condition of landowner and slave status since it could not be converted into capitalized income from colonial trade. This exclusion, therefore, of property relations did not exclude property. He lived, throughout the time of slavery, this greater contradiction represented by the slave in a capitalist economy of slave-labor production. (1986, p. 38)

The quilombola peasant has a preponderant characteristic: that makes $\mathrm{him} / \mathrm{her}$ different from the capitalist model of sociometabolic reproduction which is the relation of production through labor. Work for peasants is, par excellence, educational. Peasant economy is distinguished by family work, subsistence economy, family ownership and land control as a constituted right, that is, control of the means of production. Besides, their production planning is not associated with the chronological time of capital, which differentiates them from other subjects and from capitalist properties.

Yet, another teacher talks about the pride of a child for its peasant and quilombola background.

I think we must pass to our students, is that the education of the quilombola is an education that has been built in many social ways, because they have rights. The other day, I asked my students what they 
wanted to be when they grew up, and they said they wanted to be like their parents, to take care of the land! Stay in the sun! Plant and harvest many crops! Whoever was from the countryside and quilombola was his hero. They talked about identity, and also stated that we do not realize that they have this identity recognized,... of being from the countryside, quilombola and black. (Maria da Luz de Jesus)

However, this statement reveals with great propriety that children identify themselves with the countryside and their quilombola existence. The teacher herself recognizes that children need to adopt an education of the countryside and quilombola identities, based on the recognition and appreciation of this cultural diversity. An identification with the field, with the land to plant and harvest, thus guaranteeing their subsistence, and how being from the quilombola ethnic group is a peculiar feature to add to the necessary elements, making up the Quilombola peasant category.

Although the quilombola peasant understands the land as everyone's good, which is configured as the space of production and reproduction of life, the quilombola resistance and the struggle for the land reflect the attempts to confront the projects of the capital.

In this context, the implementation of the articles that make up the Curriculum Guidelines for Quilombola School Education can give visibility to the peculiarities of what is constructed and legitimized in the daily life of these peoples through their history, their knowledge. In other words, life materialized in that dialectical and dynamic process.

Fernandes states that

they break with the past and the traditionalist pattern of passive, subaltern and subservient accommodation before the white. Consequently, the concern of this group of "people of color" is not restricted to "earn a living". "They are fighting for equal opportunities and equal treatment." (2007, p. 71)

Reflecting on the situation of black people in class society, and observing the political and social organization to which they were relegated, the author emphasizes that they leave the condition of passive and subaltern to the reality found and strive for equal opportunities and for equal treatment. In this perspective, we understand that the field quilombos were also ways to pursue valorization and recognition of their modes of production through a work that is socially educational and constructed by this identity subject we have called the Quilombola peasant.

Woortmann (1997) understands the social reproduction of the peasantry as production of material goods by the peasant family, but valorizing its cultural production. The author does not deny the historical processes occurred from the reproduction of a peasantry, which represents different 
ways of life. Garcia and Monteiro (2015) add that "the land for the peasants is not only the unit in which they engage their labor force to produce material conditions, subordinated to the logic of capital. Their relationship with the land would be imbued with symbolic values, a morality, an ethics and a social hierarchy" (p. 139) Thus, the relations that take place within the quilombos do not pervade the mercantilist and individualistic issues typical of the capitalist model, by the exchange of constant knowledge among their relatives and their historical background.

Figure 2 shows this organization based on the MHD for a better understanding of the quilombola peasant category emerging from the empirical data of our research.

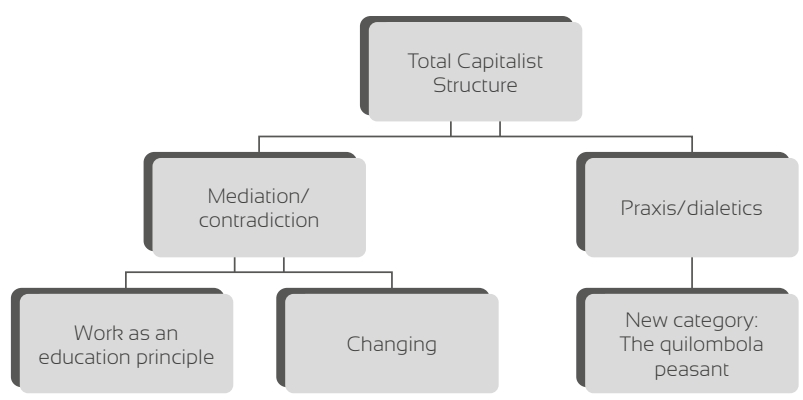

Figure 2. Organization chart based on the MHD of the new category: the quilombola peasant.

Source: Elaborated by the author.

This organization reflects the path taken to define the quilombola peasant category. The totality of the capitalist structure affected the country and quilombola subjects, first through the denial of the right to land, and then by means of the ethnic oppressions arising from the slave model in Brazil, as well as the field exodus phenomenon they have faced.

However, one of the contradictions found within this dichotomous society that transforms work as a way of alienation and not a mechanism to educate is that reparation of public policies - namely, the public policy of quilombola school education - that need to be recognized by the municipal public power and implemented as mechanisms which, in the social praxis exercised by members of the quilombola community, become educational work, as they are means of struggle to guarantee their own existence. Notice that the organization shown in the chart is by no means hierarchical, since we understand that these categories exist within the multiple determinations of a phenomenon. It is just a proposal to reflect upon the way in which they constantly overlap in this subject that, through labor, becomes aware of its own existence. 
Ramos, Frigotto and Caviatta (2004) agree that work is preponderant for the ontology of human beings as social beings, it is the essence of the social being. The formation of consciousness, as stated by Marx and Engels (1998), comes from the action of men for the transformation of nature through work. Thus, work is not employment. It is not only a historical form of work in society, it is the fundamental activity by which human beings humanize themselves, create, expand their knowledge, and become more perfect. Work is the structuring basis of a new kind of being, of a new conception of history.

We adopt this understanding of work as an educational principle, humanizing work, conscientious form, ethnic identity and with the ontological capacity to bring about changes in the life of the quilombola peasant subjects that are remnants of the quilombola communities.

It is important to understand the concept of remnants of quilombos that is in Federal Decree 4.887/2003: "Belonging to the communities of the quilombos, ethnic-racial groups, according to self-attribution criteria, with their own historical trajectory, endowed with specific territorial relations, with a presumption of black ancestry related to resistance to historical oppression suffered" (Brazil, 2003).

This concept legitimates a legal form, a struggle waged by the Black Movement and the Quilombola Movement for the recognition of their status as quilombola subjects with their own features, including having preserved their territories of identity.

On this matter, Garcia and Monteiro point out:

The black, field and urban communities that are currently leading self-recognition as remnants of quilombos, an identity coming from outside a policy of territorial planning, which is the only alternative found by these communities, both to ensure the right to land, as access to certain social conditions were historically denied them. $(2015$, p. 315)

The authors point out that what motivated the field and urban black communities to strive for recognition and for their territories of identity was the historical loss of the right to land, and the denial of their right to their condition of existence. Therefore, it was not the memory of a quilombo that existed in the times of slavery what motivated this struggle, but the existing quilombo, composed of workers from this space called the field, where the quilombolas established their livelihoods and life in a praxis that is renewed dialectically in the daily life of social relations.

Although Garcia and Monteiro (2015) state that one cannot deny the subjectivity of the quilombolas who through the land and the relationships that are permeated from it also builds their consciousness of belonging of identity and ancestrality as symbolic forms to rescue their self-esteem, 
and strengthen their ability to fight against discrimination, prejudice and racism. This ability to intervene through its educational praxis from work makes the field and quilombola subjects a category of peasant rationality quite present within today's quilombola communities.

Thus, the Quilombola peasant category represents those individuals who preserve peasant identity based on the peasantry; ethnic diversity in constant confrontation with capital, but who sustain a primacy of resistance and resilience constituted and constantly changing, in favor of the recognition of their right to land and its culture to transform society.

\section{Conclusion}

The Curriculum Guidelines for Quilombola School Education (Brazil, 2012) are supported by the National Guidelines for Field Education (Brazil, 2002) when defining quilombola subjects as field peoples. They are basic norms for their enforcement in Brazilian municipalities, seeking to meet the specificities and peculiarities of the subjects living in the countryside, marked by secular resistance against discrimination, racism and the farm/ city dichotomy caused by the capitalist mode of alienation and segregation. The Quilombola peasant category is the representation of the field workers living in the field quilombos, with their particular modes of production, knowledge, and stories. Their way of living, being part of the working class, comprises a territory in constant dispute with the capitalist model that has a predatory capacity. However, the quilombolas want recognition and legitimation of their existence, mainly, through education.

Even though we are aware of the fact that the transformation of capitalist society structures will not happen through the implementation of educational policies, we understand that they are constitutional rights and point to the materialization of the struggles of the quilombola peasant black people.

\section{References}

Abramovay, R. (2007). Paradigmas do capitalismo Agrário em Questão (3ª edição). Edusp.

Brazilian Constituição. (2003). Decreto 4887, de 20 de novembro de 2003.

Cheptulin, A. (2004). A Dialética materialista-Categorias e Leis da Dialética, vol. 02 (trad. Leda Rita Cintra Ferraz). Coleção Filosofia. AlfaÔmega, Série 1.

Conselho Nacional de Educação. (2004). Parecer CNE/CP 003. Diretrizes Curriculares Nacionais para a Educação das Relações Étnico-Raciais. 
Conselho Nacional de Educação. (2006). Parecer Cne/CEB n ${ }^{0}$ 1. Dias Letivos para a aplicação da Alternância nos Centros Familiares de Formação por Alternância.

Fernandes, F. (2007). O Negro no Mundo dos Brancos ( $2^{\text {a }}$ edição). Global Editora.

Fernandes, F. (1978). A Integração do Negro na Sociedade de Classes (3a edição). Ática.

Fórum Nacional de Educação do Campo-Fonec. (2012). Notas para análise do momento atual da Educação do Campo. Brasília. http://www. editoraunesp.com.br/catedra/publicacoes_relatorios.asp?tpl_id=5

Garcia, M. F., Junior, M. Antônio Miditiero, Viana, Pedro C. G. (Org). (2015). A Questão Agrária no Século xxı: escalas, dinâmicas e conflitos territoriais (p. 309-362). Outras Expressões.

Gomes, N. Lino. (2006) et al. Identidade e Corporeidades Negras: Reflexões sobre uma experiência de formação de professores/as para a diversidade étnico-racialAutêntica.

Kosik, K. (1997). Dialética do Concreto (6. ed.). (Trad. C. Neves e A. Toríbio). Paz e Terra.

Martins, J. de Souza. (1986). Os camponeses e a Política no Brasil: as lutas sociais no campo e seu lugar no processo político ( $3^{\text {a }}$ edição). Vozes.

Marx, K. (1993 [1843]). Introdução à crítica da filosofia do direito de Hegel. Edições 70

Marx, K. e. Engels, F. (1998). A ideologia Alemã. In Teses de Freubach (pp. 118-119). Alfa-Omega.

Marx, K. (2010). Contribuição a Crítica da Filosofia do Direito de Hegel (trad. L. Ehlers). Expressão Popular.

Mészáros, I. (2014). O poder da ideologia. (Trad. M. Lopes e P. C. Castanheira). Boitempo.

Minayo, M. C. de Souza. (Org.) Deslandes, F., Gomes, R., (2007). (Orgs.) Pesquisa Social Teoria, método e Criatividade. Editoras Vozes.

Ministério da Educação Nacional. (2012). Resolução CNE $n^{\circ}$ 08. Diretrizes Operacionais para a Educação Escolar Quilombola.

Ministério da Educação Nacional. (2007). Plano de Ações Articuladas (PAR). Relatório Público. http://simec.mec.gov.br/cte/relatorio público/ principal.php

Ministério da Educação Nacional. (2002). Resolução CNE $n^{\circ} 01$. (Educação do Campo - cultivando um Brasil melhor) Diretrizes Operacionais para a Educação Básica nas Escolas do Campo.

Ministério da Educação Nacional. (2004). Resolução $n^{\circ}$ 1. Institui Diretrizes Curriculares Nacionais para a Educação das Relações Étnico Raciais e para o Ensino de História e Cultura Afro-Brasileira e Africana. 
Ministério da Educação Nacional. (2008). Resolução nº 2/2008. Estabelece Diretrizes Complementares, normas e princípios para o desenvolvimento de políticas públicas de atendimento da Educação Básica do Campo.

Ministério da Educação Nacional. (2010). Resolução n 4. Define Diretrizes Curriculares Nacionais Gerais para a Educação Básica.

Ministério da Educação Nacional. (2010). Resolução $n^{\circ} 7$. Fixa Diretrizes Curriculares Nacionais para o Ensino Fundamental de 9 (nove) anos.

Ministério da Educação Nacional. (2010). Decreto $n^{\circ} 7.352$. Dispõe sobre a política de educação do campo e o Programa Nacional de Educação na Reforma Agrária - Pronera. Diário Oficial da União. Poder Legislativo.

Munanga, K. (2004). Uma abordagem Conceitual das noções de raça, racismo, identidade e etnia. Cadernos Penesb (Programa de Educação sobre o Negro na Sociedade Brasileira) 5, 15-23.

O'Dwyer E. Cantarino. (1995) (Org.). Remanescentes de quilombos no Brasil. Boletim da ABA - Terras de Quilombos.

Oliveira, W. T. Farias. (2017). Diversidade Étnico-racial no Currículo Infantil: o estudo das práticas educativas em uma EMEI da cidade de São Paulo. Editora Vozes.

Presidência da República Federativa do Brasil. (1988). Constituição da República Federativa do Brasil.

Presidência da República Federativa do Brasil. (2003). Lei no 10.639. Diretrizes Curriculares Nacionais para a Educação das Relações Étnicas- Raciais e para o ensino de História e Cultura Afro-Brasileira e Africana.

Presidência da República Federativa do Brasil. (2008). Lei n 11.645. Diretrizes Curriculares nacionais para a Educação das Relações Étnico-Raciais para o Ensino de História e Cultura Afro-brasileira Africana e Indígena.

Presidência da República Casa Civil Subchefia para Assuntos Jurídicos. (2003). Decreto $n^{\circ}$ 4.887. Regulamenta o procedimento para identificação, reconhecimento, delimitação, demarcação e titulação das terras ocupadas por remanescentes das comunidades dos quilombos de que trata o art. 68 do Ato das Disposições Constitucionais Transitórias.

Ramos, M. Nogueira. (2004). O projeto unitário de ensino médio sob os princípios do trabalho, da ciência e da cultura. In G. Frigotto Gaudêncio e M. Ciavatta (Org.). Ensino médio. Ciência, cultura e trabalho. $\mathrm{MEC} / \mathrm{Setec}$.

Santos, A. Ramos. (2012). Análise das políticas públicas educacionais implementadas no contexto das escolas municipais. Prefeitura Municipal de Vitória da Conquista/BA. Secretaria Municipal de Educação. 
Santos, A. Ramos. (2013). Ocupar, resistir e produzir, também na Educação! O mst e a Burocracia Estatal: Negação do Consenso. Ed. Paco.

Santos, A. Ramos. (2016). Aliança (neo) desenvolvimentista e decadência ideológica no campo: movimentos sociais e reforma agrária do consenso. CRV.

Secretaria Municipal da Educação. (2016). Setor de Legalização e Estatística da SMED.

Secretaria Municipal da Educação. (2017). Setor de Legalização e Estatística da SMED.

Silva, M. Nilza. (2006). Nem para todos é a cidade: segregação urbana racial na cidade de São Paulo. Fundação Cultural Palmares.

Silva, M. Nilza. (2012). População Negra: segregação e invisibilidade em Londrina. In: T. M. P. Muller (coord.); R. E. Santos (org.). Questões urbanas e racismo. DP et alii; ABPN.

Socorro, P. E. Villasmil et al. (2019). Políticas públicas educativas en el contexto de América Latina. Una perspectiva de la educación rural/educación del campo en Venezuela y Brasil. Revista Brasilera de Educación, 35. https://www.scielo.br/scielo.php?pid=S0102-46982019000100434 \&script=sci_arttext, https://doi.org/10.1590/0102-4698196116

Teixeira, A. Relatório da Inspetoria Geral do Ensino do Estado da Bahia, apresentado como Anuário do Ensino do Estado da Bahia. Salvador (1925).

Teixeira, A. Relatório apresentado ao Ex. Sr. Cons. Bráulio Xavier da Silva Pereira, Secretário do Interior, Justiça e Instrução Pública pelo Diretor Geral da Instrução Pública, para ser encaminhado ao governador do Estado da Bahia. Imprensa Oficial do Estado (1928).

Woortmann, K. (1997). O Trabalho da Terra: a lógica e a simbologia da lavoura camponesa. UNB. 